\title{
Molecular comparison of the IncX plasmids allows division into IncX1 and IncX2 subgroups
}

\author{
Clive S. Jones, David J. Osborne† and John Stanley* \\ Molecular Genetics Unit, National Collection of Type Cultures, Central Public Health Laboratory, \\ 61 Colindale Avenue, London NW9 5HT, UK
}

(Received 30 July 1992; revised 18 November 1992; accepted 17 December 1992)

\begin{abstract}
We have investigated molecular relationships and evolution of plasmids classified genetically to incompatibility (Inc) group X, in particular by comparison of plasmids from the pre-antibiotic era (PAE) with contemporary Rplasmids. On the basis of restriction analysis, R6K, the best-described and 'prototype' plasmid of the IncX group, exhibited little similarity with the other plasmids in this Inc group. Other contemporary IncX R-plasmids exhibited a substantial degree of interrelationship, and were also related to PAE IncX plasmids. When the origin of plasmid replication of $R 6 \mathrm{~K}$ was used as a replicon probe, $\mathrm{R} 6 \mathrm{~K}$ was the only plasmid tested which exhibited homology. Other contemporary and PAE IncX plasmids exhibited homology with the origin of plasmid R485. These data suggest that the IncX group should be subdivided. R485 may be regarded as representative of the major subgroup present before and after the advent of antibiotic selection pressure. Plasmids of this subgroup, IncX1, possess an internal region which yields five characteristic EcoRV fragments. R6K may be regarded as representative of subgroup IncX2, of which it is presently the sole well-described member. The antibiotic resistances encoded by contemporary IncX R-plasmids are due to insertion of identifiable transposons in progenitor plasmids identical to the $\mathbf{R 4 8 5}$ subgroup of PAE IncX plasmids.
\end{abstract}

\section{Introduction}

The conjugative plasmid R6K, first detected in Escherichia coli, was found to be a multicopy R-plasmid of $40 \mathrm{~kb}$ (Kontomichalou et al., 1970) and was assigned to a new incompatibility group, IncX (Hedges et al., 1973). The two best-studied representatives of this group, as defined genetically (Datta, 1979), are R6K and R485. Physical-genetic maps of these plasmids are presented in Fig. 1, which shows that there are few if any common features. The two plasmids encode structurally similar pili, but R485 also encodes a second unique pilus type. The plasmids are incompatible in that stable 'doubles' cannot be formed, although their (bidirectional) segregation is atypically slow (Bradley, 1982). IncX plasmids have been implicated in the acquisition and dissemination of transferable drug resistance in pathogenic enterobacteria, for example in animal strains of Salmonella

*Author for correspondence. Tel. 0812004400 ext. 3738; fax 081 2007874.

$\dagger$ Present address: Department of Molecular Genetics, University of Sheffield, UK.

Abbreviation: PAE, pre-antibiotic era. typhimurium (Threlfall et al., 1986). IncX plasmids have also been shown to participate in co-integration events with virulence-associated plasmids in Salmonella (Platt et al., 1988).

The replication of $\mathrm{R} 6 \mathrm{~K}$ is well characterized and a variety of small autonomously-replicating derivatives have been constructed (Filutowicz et al., 1985). It contains three origins of replication which function in vitro, designated $\alpha, \beta$ and $\gamma$ (see Fig. 1). A structural gene for the replication-initiation protein has been characterized (Crosa, 1980; Kolter \& Helinski, 1978). Studies with R485 showed that in vivo the incompatibility reaction between this plasmid and $\mathrm{R} 6 \mathrm{~K}$ depended on interaction between a functional R485 replicon (see Fig. 1) and an active R6K $\beta$-origin (Stalker \& Helinski, 1985). Other R6K replication functions were not involved in its incompatibility with R485. No extensive DNA homology was found between the replicons of R485 and R6K over long nucleotide stretches (Stalker \& Helinski, 1985). Couturier et al. (1988) found no homology between a cloned probe for the $\gamma$ origin of replication of $\mathrm{R} 6 \mathrm{~K}$ (which is inactive in vivo) and other IncX plasmids studied. Two IncX plasmids hybridized with a replicon probe from IncQ plasmids. The origin of replication of R485 has been cloned (Stalker \& Helinski, 
Table 1. Plasmids and DNA probes

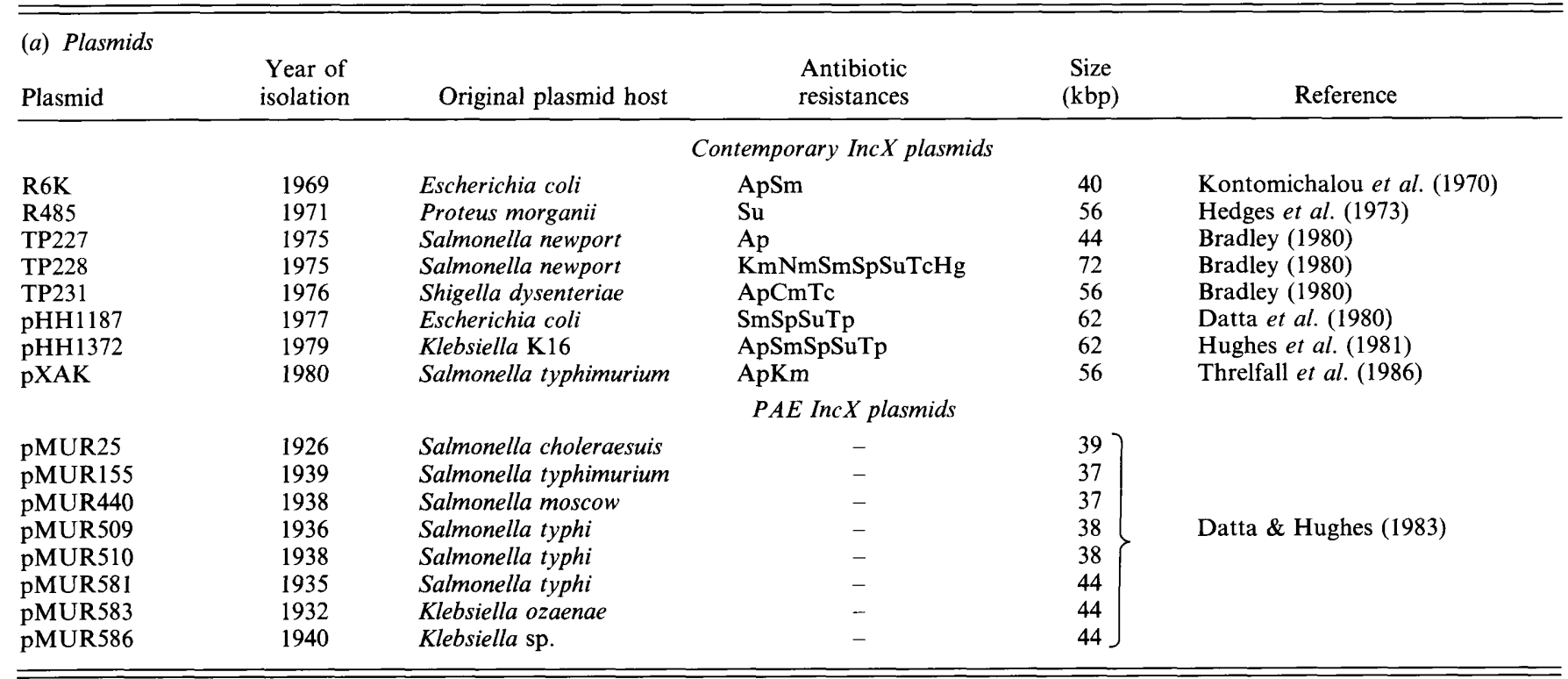

(b) DNA probes

\begin{tabular}{|c|c|c|c|c|}
\hline Probe & Restriction fragment & Clone & $\begin{array}{l}\text { Origin } \\
\text { element }\end{array}$ & Reference \\
\hline $\operatorname{IncX}_{\mathrm{R} 485}$ & EcoRI-TaqI $/ 0.59$ & pDS49 & R485 & Stalker \& Helinski (1985) \\
\hline $\operatorname{Inc} X_{P_{485}}$ & $E c o \mathrm{RI} / 2.75$ & pDS20 & R485 & Stalker \& Helinski (1985) \\
\hline $\operatorname{IncX}_{\mathrm{R} 6 \mathrm{~K} \text { origin }}$ & HindIII $/ 0 \cdot 9$ & pULB2405 & R6K & Couturier et al. (1988) \\
\hline IncQ & EcoRI/0.357 & pULB2424 & R1162 & Couturier et al. (1988) \\
\hline $\operatorname{tnp} A$ & BamHI-HaeII/1.0 & pUB2403 & $\operatorname{Tn} 3$ & Ward \& Grinsted (1987) \\
\hline tnp & Bam $\mathrm{HI} / 0 \cdot 9$ & ColE $1:: \operatorname{Tn} 7$ & Tn7 & Barth et al. (1978) \\
\hline
\end{tabular}
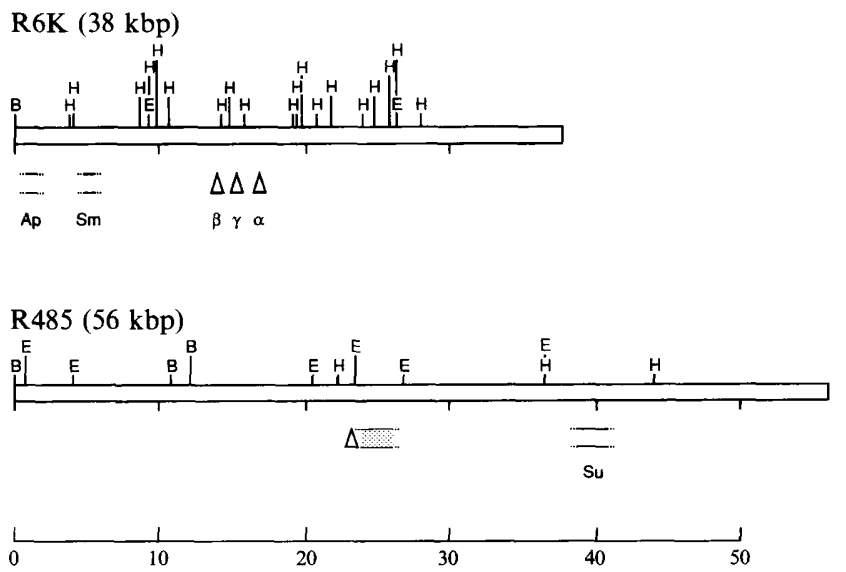

Fig. 1. Physical-genetic maps of archetypal IncX plasmids. Maps were redrawn from the data of Kolter \& Helinski (1978) and Stalker \& Helinski (1985) and aligned from the single BamHI site, which is the only apparent conserved feature in these plasmids. Restriction sites are indicated above the maps as follows: B, BamHI; E, EcoRI; H, HindIII. Replication origins are indicated by arrowheads. Genes encoding antibiotic resistance are shown as open boxes, and the gene encoding the trans-activator of $\mathbf{R} 485$ replication is shown by a stippled open box. The scale in $\mathrm{kbp}$ is shown below the maps, and at the bottom of the figure.
1985) but its molecular relatedness among IncX plasmids has not been documented.

Pathogenic enterobacteria (Salmonella, Shigella, Escherichia, Klebsiella and Proteus spp.) from human infections of wide geographical distribution were collected by E. D. G. Murray between 1917 and 1954, the pre-antibiotic era (PAE), and preserved in sealed glass tubes on agar slants. When opened in 1980, about $70 \%$ of these PAE isolates were found to be still viable. They represent bacterial genera, of which contemporary examples frequently contain plasmids encoding multiple antibiotic resistance. In a study of PAE plasmids in the Murray Collection, Hughes \& Datta (1983) made a genetic analysis of transferable plasmids among PAE Enterobacteriaceae, showing that conjugative plasmids of the same Inc groups existed in enterobacteria before and after the medical use of antibiotics. Several other molecular genetic studies (e.g. Green, 1984; Jones \& Stanley, 1992; Sedgewick et al., 1989) have employed Murray PAE strains to elucidate the evolution of plasmid and other genes.

The objective of this study was to characterize 


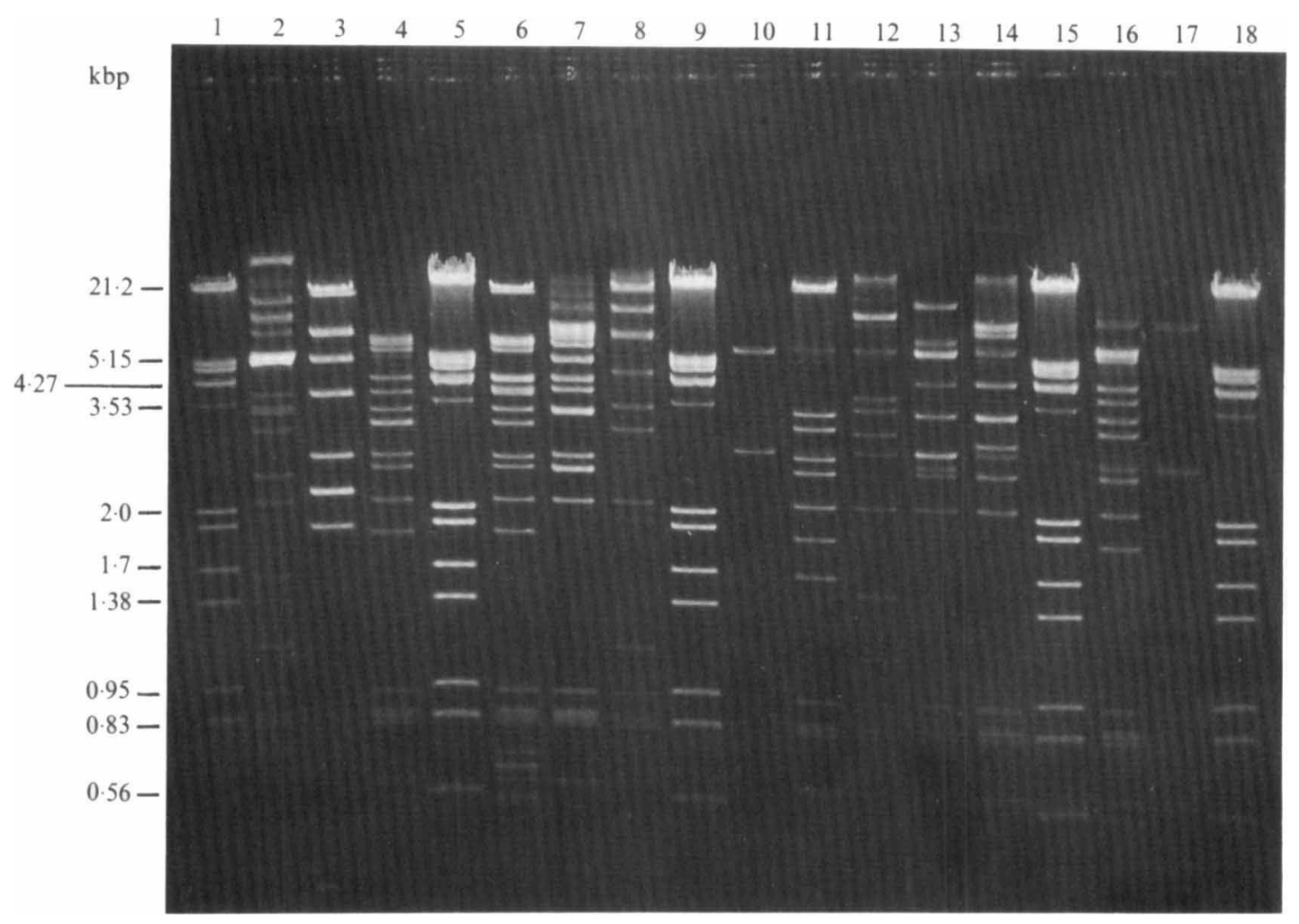

Fig. 2. EcoRV fingerprint of contemporary and PAE IncX plasmids. The molecular size markers used were derived from an EcoRI/HindIII digest of phage $\lambda$ (tracks 1, 5, 9, 15 and 18). The other tracks contained: track 2, pHH1187;3, R6K;4, TP227;6, TP228; 7, TP231; 8, R485; 10, R300B; 11, pMUR509, R300B; 12, pMUR583, R300B; 13, pMUR25, R300B; 14, pMUR155, R300B; 16, pMUR440, pHH1310a; 17, pHH1310a. Plasmids R300B $\left(\mathrm{Sm}^{\mathrm{r}} \mathrm{Su}^{\mathrm{r}}\right)$ and $\mathrm{pHH} 1310 \mathrm{a}\left(\mathrm{Ap}^{\mathrm{r}}\right)$ appear together with individual PAE plasmids because of their use as co-mobilized indicators of self-transfer by the PAE plasmids (Datta \& Hughes, 1983).

molecular relationships among IncX plasmids, and to compare contemporary IncX R-plasmids with PAE IncX plasmids from the Murray collection. We have sought thereby to provide a molecular phylogenetic classification of this plasmid group.

\section{Methods}

Bacteria, media and culture conditions. IncX plasmids used in this study, their isolation dates and original host are listed in Table 1. PAE plasmids were analysed in $E$. coli $\mathrm{K} 12 \mathrm{~J} 53$, a recipient strain to which they had been transferred using the plasmids $\mathrm{R} 300 \mathrm{~B}$ or $\mathrm{pHH} 1310 \mathrm{a}$ as co-mobilized marker plasmids (Datta \& Hughes, 1983). All strains were stored on nutrient agar slopes at room temperature and grown on nutrient agar $/$ broth at $37^{\circ} \mathrm{C}$ for $18 \mathrm{~h}$. Antibiotics (Sigma) were added to media at the following concentrations $\left(\mu \mathrm{g} \mathrm{ml}^{-1}\right)$ for plasmid selection: ampicillin, Ap (100); chloramphenicol, Cm (25); tetracycline, Tc (10).

Plasmid analysis and DNA hybridization. Analysis of plasmid DNA was done by the method of Kado \& Liu (1981), and plasmids were visualised by electrophoresis on horizontal $0.7 \%(\mathrm{w} / \mathrm{v})$ agarose gels. Agarose gels were vacuum-blotted (Pharmacia-LKB Vacu-Gene apparatus) onto Hybond $\mathrm{N}$ nylon membrane (Amersham) for hybridization experiments. Plasmid DNA for restriction enzyme analysis or for preparation of probe fragments was extracted from $500 \mathrm{ml}$ nutrient broth cultures, using cleared lysates and $\mathrm{CsCl} /$ ethidium bromide density gradient purification (Sambrook et al., 1989). DNA probe fragments were excised after digestion with enzymes listed in Table 1 . Whole plasmid DNA or restriction fragments were separated on $1 \%$ low-melting-point agarose (Gibco-BRL), prior to labelling with digoxygenin-11-dUTP (Boehringer-Mannheim) by random-primed synthesis in agarose. Membrane filters blotted from agarose gels (see above) were hybridized at $68^{\circ} \mathrm{C}$ in $5 \times \mathrm{SSC}$, and thereafter stringently washed (final wash in $0 \cdot 1 \times \mathrm{SSC}$ at $55^{\circ} \mathrm{C}$ ). $[1 \times \mathrm{SSC}$ is $0.15 \mathrm{M}-\mathrm{NaCl}$, $0.015 \mathrm{M}$-sodium citrate, $\mathrm{pH} 7.0 \mathrm{]}$. For certain experiments, washing conditions of reduced stringency $\left(2 \times \mathrm{SSC}\right.$ at $\left.55^{\circ} \mathrm{C}\right)$ were employed. Filters were colour-developed according to Boehringer-Mannheim's instructions. DNA probe fragments used in the study are listed in Table 1.

\section{Results}

\section{Common features of a major group of IncX plasmids}

CsCl-purified DNA was digested with the restriction enzymes $E c o$ RV, BamHI, BglII, EcoRI, PstI and SalI. In all digests, R6K showed very few or no bands in common with any other IncX plasmids (for Eco RV, see Fig. 2; other data not shown) and on this basis it was judged to be distantly related. For other IncX plasmids, EcoRV digests, which yielded a wide range of fragment sizes, were used for general comparative analysis (see 


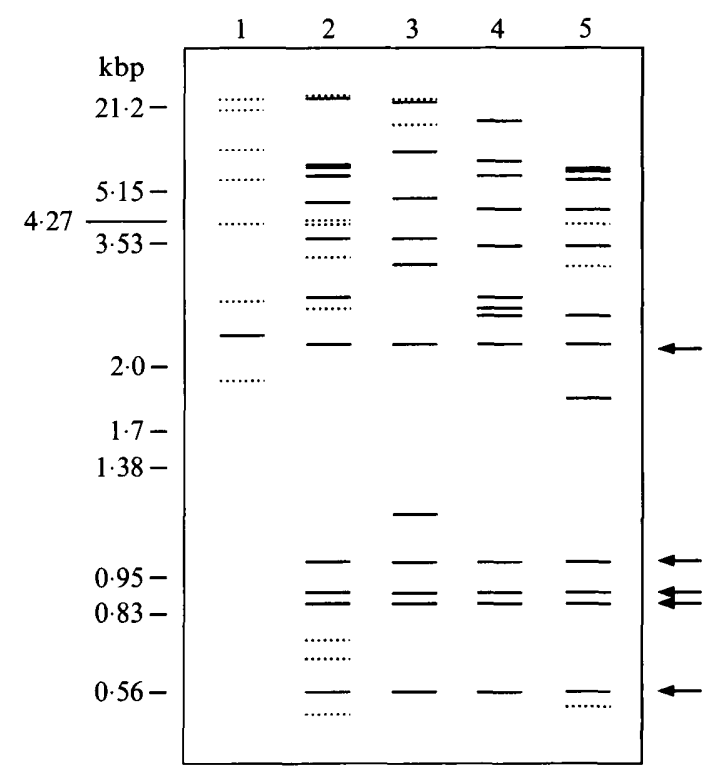

Fig. 3. Diagrammatic representation of pMUR25 plasmid homology relationships. EcoRV digests of representative IncX plasmids were transferred to nylon membrane and probed with labelled pMUR25 DNA. The membrane filter which is represented was washed under conditions of high stringency. Solid lines represent fragments which showed homology to this probe; dotted lines denote non-homologous fragments. The restriction fragments due to $\mathrm{R} 300 \mathrm{~B}$ and $\mathrm{pHH} 1310 \mathrm{a}$ have been removed. The tracks contained: $1, \mathrm{R} 6 \mathrm{~K} ; 2$, TP228; 3, R485; 4, pMUR25; 5, pMUR440. Molecular size markers are indicated on the left. Conserved 'core-region' fragments of the IncX1 subgroup are arrowed on the right.

Fig. 2). One obvious feature of EcoRV digests was that none of the eight EcoRV fragments of R6K (Fig. 2, track 3 ) was conserved among other IncX plasmids. On the other hand, common fragments of $2 \cdot 1,0.94,0.84,0.82$ and $0.63 \mathrm{kbp}$ were found in all plasmids except R6K. These five EcoRV fragments exhibited features of a conserved region specific to a plasmid subgroup. With respect to the PAE IncX plasmids there were identical digest patterns for pMUR509 (Fig. 2, track 11) and pMUR510 (not shown), and also for pMUR583 (Fig. 2, track 12), pMUR581 and pMUR586 (not shown), although these plasmids were isolated from Salmonella typhi, Klebsiella ozaenae and Klebsiella sp. at different dates. Plasmids pMUR583, pMUR25 and pMUR155 showed only minor EcoRV site variations (Fig. 2, tracks 12,13 and 14). Greater variation was seen among the contemporary IncX R-plasmids, but there were clearly discernible common regions in R485 and pHH1187 (eight common Eco RV fragments in Fig. 2, tracks 8 and 2), and in pHH1372 (eight common fragments, data not shown). Similarly, plasmids TP227, TP228 and TP231 shared at least ten common $E c o$ RV fragments with each other (Fig. 2, tracks 4, 6 and 7) and with pXAK (data not shown). There were two sites for PstI in most of the PAE plasmids, but pMUR581, pMUR583, pMUR586 and pMUR25 contained a third site. Four, five or six PstI sites were found in all contemporary IncX R-plasmids (data not shown).

\section{Homology relationships with pMUR25}

Total plasmid DNA from the earliest-isolated PAE plasmid, pMUR25, was labelled and used to evaluate homology relationships among all IncX plasmids. Fig. 3 presents a diagrammatic representation of the results of such experiments. The previously discussed five common EcoRV fragments of contemporary and PAE plasmids all showed homology with pMUR25 as shown by the arrows on the right of Fig. 3. Six to eight other EcoRV fragments in contemporary plasmids and virtually all EcoRV fragments of the PAE plasmids showed homology. Addition of the molecular sizes of the five conserved homologous fragments found in both PAE and contemporary plasmids suggested that they might represent a 'core-region' of about $6 \mathrm{kbp}$. This was not present in R6K (Fig. 3, track 1), in which only an EcoRV fragment of $2 \cdot 2 \mathrm{kbp}$ exhibited homology with pMUR25. The bands not hybridizing in the contemporary plasmids were presumed to have arisen from recombinational events including transposition of mobile DNA during acquisition of antibiotic-resistance genes.

\section{Evidence for an R485 Inc Rep homology group}

Data obtained from hybridization experiments with replicon probes are presented in Table 2. Seven out of eight contemporary R-plasmids and all eight PAE plasmids exhibited homology with the replication origin of R485. When the R485 origin was used to probe EcoRI digests (Fig. $4 a$ ) of representative plasmids from each group, all except R6K (track 3) exhibited homology (Fig. $4 b$ ). It is noteworthy that this $0.59 \mathrm{kbp} \mathrm{R} 485$ origin probe detected two homologous EcoRV fragments in all these plasmids (in pMUR155, track 13, these were comigrating). A $2.75 \mathrm{kbp} E c o$ RI fragment of R485 encoding a trans-activator of replication (Stalker \&

Fig. 4. Two groups of IncX replicons. (a) EcoRI digest of contemporary and PAE IncX plasmids. The tracks contained: track 1; phage $\lambda$ EcoRI/HindIII digest; 2, pHH1187; 3, R6K ; 4, TP227; 5, TP228; 6, TP231; 7, R485; 8, $\lambda$ EcoRI/HindIII; 9, R300B; 10, pMUR509 R300B; 11, pMUR583 R300B; 12, pMUR25 R300B; 13, pMUR155 R300B; 14, pMUR440 pHH1310a; 15, pHH1310a; $\lambda$ EcoRI/HindIII. (b) Southern blot of $(a)$, hybridized with the $\mathrm{X}_{\mathrm{R} 485}$ replicon probe. 


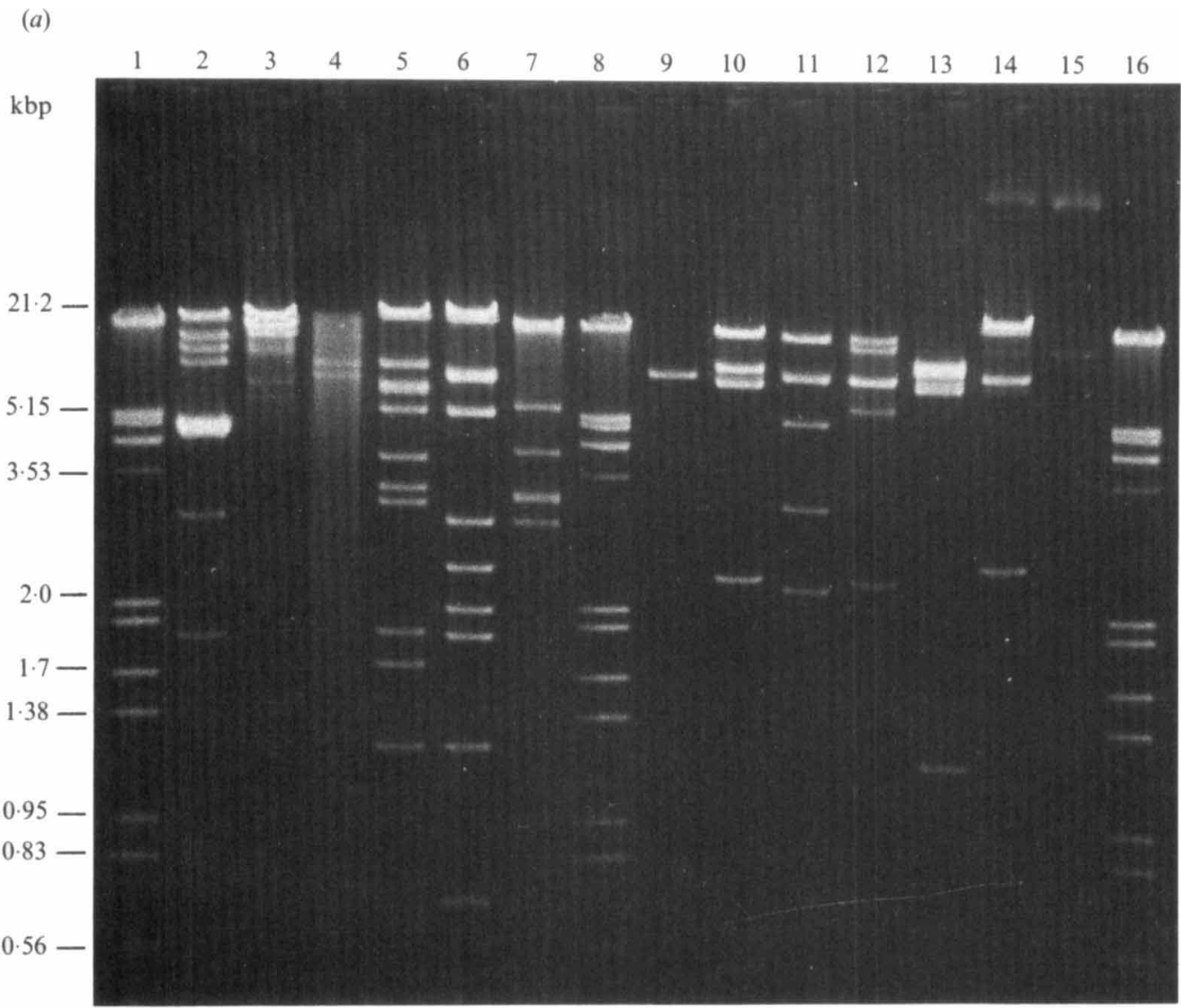

(b)

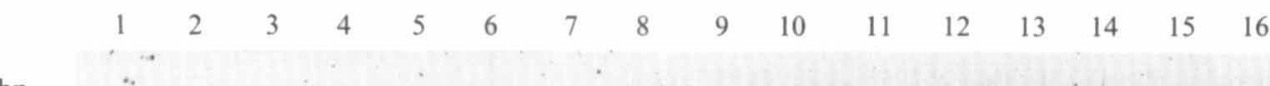
kbp

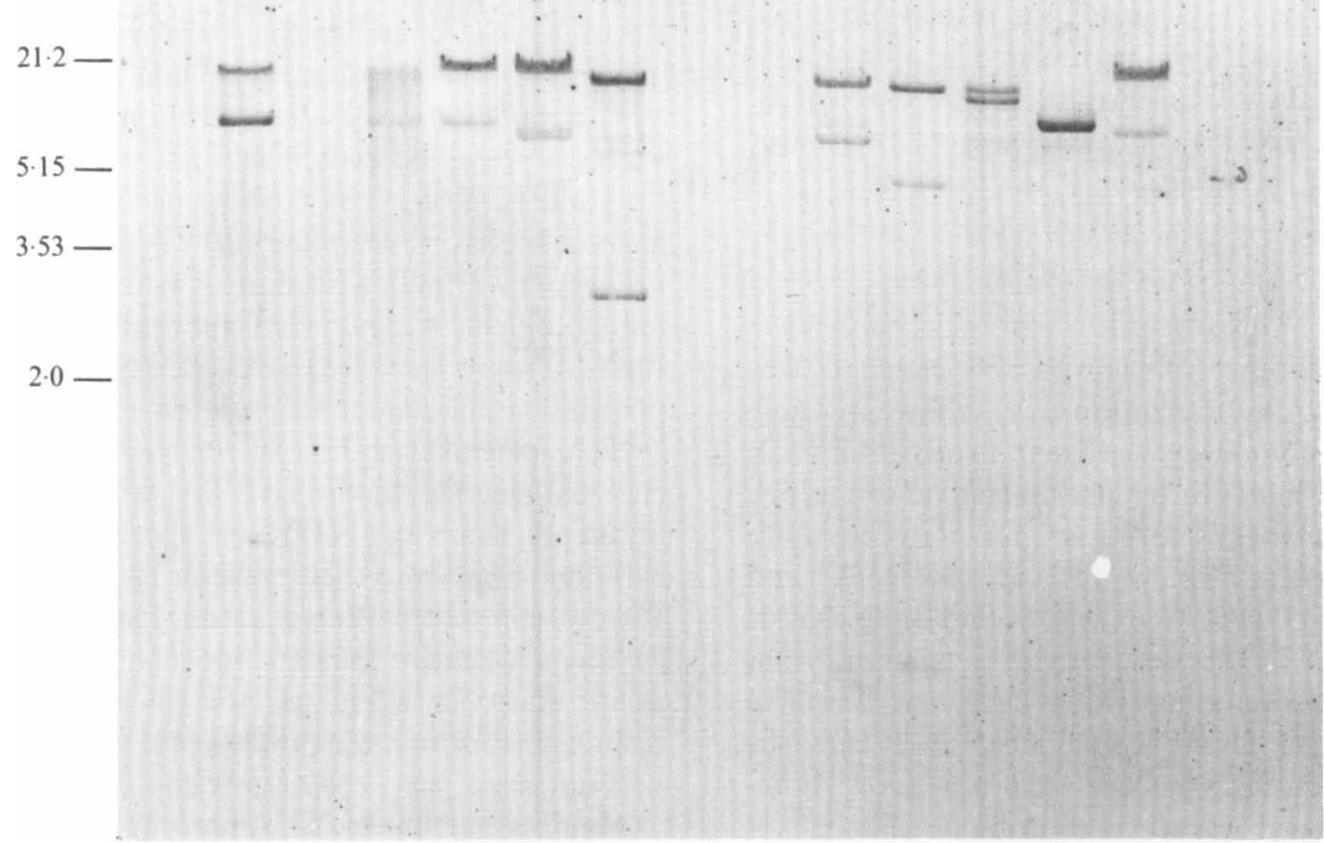




\section{Table 2. DNA probe homologies among IncX plasmids}

The five Inc/Rep and three transposase probes are listed at the top; contemporary R-plasmids and PAE plasmids are listed down the Table. Results of stringent hybridization experiments (see Methods) are indicated as follows: + , strong homology; - no homology; p, partial (weak) homology.

\begin{tabular}{lcccccc}
\hline \hline & $\mathrm{X}_{\mathrm{R} 6 \mathrm{~K}}$ & $\mathrm{X}_{\mathrm{R} 485}$ & $\mathrm{Q}$ & $\mathrm{Tn} 3$ & $\operatorname{Tn} 7$ & $\mathrm{Tn} 21$ \\
\hline R6K & + & - & - & + & - & - \\
R485 & - & + & $\mathrm{p}$ & - & - & - \\
TP227 & - & + & - & + & - & - \\
TP228 & - & + & - & - & - & + \\
TP231 & - & + & - & + & - & + \\
pHH1187 & - & + & $\mathrm{p}$ & - & + & - \\
pHH1372 & - & + & - & + & + & - \\
pXAK & - & + & - & + & - & - \\
pMUR25 & - & + & - & - & - & - \\
pMUR155 & - & + & - & - & - & - \\
pMUR440 & - & + & - & - & - & - \\
pMUR509 & - & + & - & - & - & - \\
pMUR510 & - & + & - & - & - & - \\
pMUR581 & - & + & - & - & - & - \\
pMUR583 & - & + & - & - & - & - \\
pMUR586 & - & + & - & - & - & - \\
\hline \hline
\end{tabular}

Helinski, 1985) reacted uniquely with these plasmids and not with R6K (data not shown). Conversely, even under conditions of reduced stringency (see Methods), R6K was the only plasmid which reacted with either of two IncX replicon probes representing the $\gamma$ or the $\alpha$ and $\beta$ origins of R6K. It should be noted that this lack of homology with the $\beta$ origin of $\mathrm{R} 6 \mathrm{~K}$ has not been reported previously.

Plasmids R485 and pHH1187 showed weak partial (about $20 \%$ ) homology with an IncQ probe, but no other plasmids did so. As a whole, the results presented above are consistent with the existence of major (R485type) and minor (R6K-type) groups of IncX plasmids, and with the fact that no representatives of the minor (R6K) group were found among PAE plasmids.

\section{Transposon homology}

The presence or absence of transposable elements was determined by DNA hybridization and is shown in Table 2. No transposon homology was found in any PAE IncX plasmid. Of the contemporary plasmids, Tn 3 homology was found in all plasmids carrying ampicillin-resistance markers (i.e. R6K, TP227, TP231, pHH1372 and pXAK). Homology with Tn7 was found in plasmids pHH1187 and pHH1372, which carry a trimethoprimresistance marker. Homology with Tn21 was found in plasmids TP228 and TP231. R485, although it carries a sulphonamide-resistance marker, did not show homology with any tested transposase probe (Table 2).

\section{Discussion}

From the digest patterns of IncX plasmids shown in Figs 2 and 3 it can be seen that a conserved region exists in one subgroup of these plasmids. A common evolutionary origin is therefore indicated for contemporary and PAE IncX plasmids other than R6K. The 'core-region' characterized is composed of five small and easily resolved EcoRV fragments.

In contemporary IncX plasmids, insertion of readily identifiable transposons was demonstrated. Thus in the IncX group, complex R-plasmids have been produced by sequential addition of transposons, such as of $\operatorname{Tn} 3$ and $\mathrm{Tn} 21$ in the case of TP228. Evolutionarily-related or identical (pMUR583-pMUR581-pMUR586 type) conjugative plasmids, were evidently present in the Enterobacteriaceae (see Table 1) before the advent of selection pressures due to the widespread use of antibiotics. The PAE plasmids have few $P$ stI sites, presumably reflecting their adaptation to Enterobacteriaceae such as Providencia. Their contemporary relatives on the other hand have up to six PstI sites, imported by transposons such as Tn3. Thus, the evidence of this study confirms that PAE plasmids readily became vehicles for the spread of antibiotic-resistance transposons.

The molecular fingerprint homology analysis reported here indicates that although R6K is indeed incompatible with other members of the IncX group of PAE and contemporary origin, its molecular evolution is distinct. We therefore consider that R6K exemplifies an incompatibility sub-group which is of minor prevalence. By way of precedent, the IncHI group plasmids have been divided into Inc HI1, HI2 and HI3 on the basis of relative homology relationships (Grindley et al., 1973; Roussel \& Chabbert, 1968). We propose that in a similar manner, the R485 subgroup of Inc group X should be termed IncX1, since it is currently more prevalent, and we have presented evidence of its existence prior to the isolation of R6K. The R6K subgroup should then be termed IncX2. IncX plasmids have been described by Prager et al. (1988), whose EcoRV fingerprints, although not complete, suggest that they may be members of IncX2. To our knowledge these are the only other IncX2 plasmid candidates so far isolated.

IncX plasmids could still be generally identified by classical genetic incompatibility with R6K or R485. Stalker \& Helinski (1985) have speculated that the twoway incompatibility between the R6K $\beta$ origin and the R485 origin reflects structural competition for a putative cellular replication or partition component. Homology relationships between the $\mathrm{R} 6 \mathrm{~K} \beta$ origin, which is that responsible for incompatibility, and other IncX plasmids had not been previously reported.

Members of the IncX1 subgroup proposed would be 
defined by possession of the core region in EcoRV fingerprints, and/or by homology with an R485 replicon probe. Some evidence was found in this study that further subgroups exist within IncX1. For example many other, larger, restriction fragments were found in common between the three 'TP' plasmids and the related PAE plasmids pMUR25, pMUR155 and pMUR440 (see Fig. 2). Similarly R485, the two ' $\mathrm{pHH}$ ' plasmids, and three PAE plasmids exhibited conserved restriction fragments other than those from the core region. At present, new members of the IncX2 group should be defined by homology with the R6K Inc/Rep probe. In view of the detailed analysis of R6K replication (Scott, 1984), the extent and distribution of this subgroup deserves further study.

\section{Osborne was supported by a CEC grant (BAP UK002).}

\section{References}

Barth, P. T., Datta, N., Hedges, R. W. \& Grinter, N. J. (1976). Transposition of a deoxyribonucleic acid sequence from $R 483$ to other replicons. Journal of Bacteriology 125, 800-810.

BRADLEY, D. E. (1980). Morphological and serological relationships of conjugative pili. Plasmid 4, 155-169.

BRADLEY, D. E. (1982). Further characterization of R485, an $\operatorname{Inc} \mathrm{X}$ plasmid that determines two kinds of pilus. Plasmid 7, 95-100.

Couturier, M., Bex, F., Berquist, P. L. \& MaAs, W. K. (1988). Identification and classification of bacterial plasmids. Microbiological Reviews 52, 375-395.

Crosa, J. H. (1980). Three origins of replication are active in vivo in the R-plasmid RSF 1040. Journal of Biological Chemistry 255, 11075-11077.

DatTA, N. (1979). Plasmid classification: incompatibility grouping. In Plasmids of Medical, Environmental and Commercial Importance, pp. 3-12. Edited by K. N. Timmis \& A. Puhler. Amsterdam: Elsevier/North Holland Press.

Datta, N. \& Hughes, V. M. (1983). Plasmids of the same Inc groups in Enterobacteria before and after the medical use of antibiotics. Nature, London 306, 616-617.

Datta, N., Dacey, S., Hughes, V., Knight, S., Richards, H., Williams, G., Casewell, M. \& ShanNon, K. P. (1980). Distribution of genes for trimethoprim and gentamicin resistance in bacteria and their plasmids in a general hospital. Journal of General Microbiology 118, 495-508.

Filutowicz, M., McEachern, M., Greener, A., Mukhopadhyay, P., Uhlenhopp, E., Durland, R. \& HelinsKi, D. R. (1985). Role of $\pi$ initiation protein and direct nucleotide sequence repeats in regulation of plasmid R6K replication. In Plasmids in Bacteria, pp. 125-140. Edited by D. R. Helinski, S. N. Cohen, D. B. Clewell, D. A. Jackson \& A. Hollaender. New York: Plenum.
Green, L., Miller, R. D., Dykhuisen, D. E. \& Harte, D. L. (1984). Distribution of DNA insertion element IS 5 in natural isolates of Escherichia coli. Proceedings of the National Academy of Sciences of the United States of America 81, 4500-4504.

Grindley, N. D. F., Humphreys, G. O. \& ANDERson, E. S. (1973). Molecular studies of $\mathbf{R}$ factor compatibility groups. Journal of Bacteriology 115, 387-398.

Hedges, R. W., Datta, N., Coetzee, J. N. \& Dennison, S. (1973). R factors from Proteus morganii. Journal of General Microbiology 77, 249-259.

Hughes, V. M. \& DatTa, N. (1983). Conjugative plasmids in bacteria of the 'pre-antibiotic' era. Nature, London 302, 725-726.

Hughes, V. M., Henderson, W. G. \& DatTa, N. (1981). Discriminating between multiply-resistant Klebsiella strains during a hospital outbreak: use of klebecin-typing and a screening test for plasmids. Journal of Hospital Infection 2, 45-54.

JoNES, C. S. \& Stanley, J. (1992). Salmonella plasmids of the preantibiotic era. Journal of General Microbiology 138, 189-197.

KADO, C. I. \& S.-T. (1981). Rapid procedure for detection of large and small plasmids. Journal of Bacteriology 145, 1365-1375.

Kolter, R. \& Helinski, D. R. (1978). Construction of plasmid R6K derivatives in vivo: characterization of the $\mathrm{R} 6 \mathrm{~K}$ replication region. Plasmid 1, 571-580.

Kontomichalou, P., Mitani, M. \& Clowes, R. C. (1970). Circular Rfactor molecule controlling penicillinase synthesis, replicating in Escherichia coli under relaxed or stringent control. Journal of Bacteriology 104, 34-44.

Platt, D. J., Taggart, J. \& Heraghty, K. A. (1988). Molecular divergence of the serotype-specific plasmid (pSLT) among strains of Salmonella typhimurium of human and veterinary origin and comparison of pSLT with the serotype specific plasmids of $S$. enteritidis and $S$. dublin. Journal of Medical Microbiology 27, 277-284.

Prager, R., Tietze, E. \& Tschape, H. (1988). DNA fingerprinting of conjugative plasmids incompatible with R6K (IncX). Journal of Basic Microbiology 28, 385-388.

Roussel, A. F. \& CHABberT, Y. A. (1978). Taxonomy and epidemiology of Gram-negative bacterial plasmids studied by DNA-DNA filter hybridization in formamide. Journal of General Microbiology 104, 269-276.

SAmbrooK, J., Fritsch, E. F. \& Maniatis, T. (1989). Molecular Cloning, a Laboratory Manual, 2nd edn. Cold Spring Harbor, NY: Cold Spring Harbor Laboratory.

SCOTT, J. (1984). Regulation of plasmid replication. Microbiological Reviews 48, 1-23.

Sedgewick, S. G., Thomas, S. M., Hughes, V. M., Lodwick, D. \& STRIKE, P. (1989). Mutagenic DNA repair genes on plasmids from the 'pre-antibiotic era'. Molecular and General Genetics 218 , 323-329.

StalkeR, D. M. \& Helinski, D. R. (1985). DNA segments of the IncX plasmid R485 determining replication and incompatibility with R6K. Plasmid 14, 245-254.

Threlfall, E. J., WaRD, L. R. \& Rowe, B. (1986). R plasmids in Salmonella typhimurium in the United Kingdom. Journal of Antimicrobial Chemotherapy 18 (Suppl. C.), 175-177.

WARD, E. \& GRINSTED, J. (1987). The nucleotide sequence of the tnpA gene of Tn21. Nucleic Acids Research 15, 1799-1806. 